\title{
Marker-assisted Selection for Coupling Phase Resistance to Tomato spotted wilt virus and Phytophthora infestans (Late Blight) in Tomato
}

\author{
Matthew D. Robbins \\ Department of Horticulture and Crop Science, The Ohio State University, \\ Ohio Agricultural Research and Development Center, 1680 Madison Avenue, \\ Wooster, OH 44691
}

\author{
Mohammed A.T. Masud \\ Vegetable Division, Horticulture Research Centre, Bangladesh Agricultural \\ Research Institute, Joydebpur, Gazipur-1701, Bangladesh
}

Dilip R. Panthee

Department of Horticultural Science, North Carolina State University, Mountain Horticultural Crops Research and Extension Center, 455 Research Drive, Mills River, NC 28759

\section{Randolph G. Gardner}

Department of Horticultural Science, North Carolina State University, Mountain Horticultural Crops Research and Extension Center, 455 Research Drive, Mills River, NC 28759

\section{David M. Francis \\ Department of Horticulture and Crop Science, The Ohio State University, Ohio Agricultural Research and Development Center, 1680 Madison Avenue, Wooster, OH 44691 \\ Mikel R. Stevens ${ }^{1}$ \\ Department of Plant and Wildlife Sciences, Brigham Young University, 287 WIDB, Provo, UT 84602}

Additional index words. Gene pyramiding, molecular marker analysis, multiple pathogen resistance, recombination suppression, resistance breeding, SCAR

\begin{abstract}
Tomato spotted wilt virus (TSWV) and Phytophthora infestans (late blight) in tomato (Solanum lycopersicum) have a worldwide distribution and are known to cause substantial disease damage. $S w-5$ (derived from $S$. peruvianum) and $P h-3$ (derived from $S$. pimpinellifolium) are, respectively, TSWV and late blight resistance genes. These two genes are linked (within $5 \mathrm{cM}$ on several maps) in repulsion phase near the telomere of the long arm on chromosome 9. The tomato lines NC592 (Ph-3) and NC946 (Sw-5) were crossed to develop an $\mathbf{F}_{2}$ population and subsequent inbred generations. Marker-assisted selection (MAS) using three polymerase chain reaction-based codominant markers (TG328, TG591, and SCAR421) was used in $F_{2}$ progeny with the goal of selecting for homozygous coupling-phase recombinant lines. From $1152 F_{2}$ plants, 11 were identified with potential recombination events between $P h-3$ and $S w-5$; of those, three were male sterile (ms-10). $F_{3}$ progeny were generated from the remaining eight $F_{2}$ recombinants, and resistance to both pathogens, or $P h-3$ and $S w-5$ in coupling phase, was confirmed in three of those. Recombination was suppressed fivefold in our $F_{2}$ population to $1.11 \mathrm{cM}$ between genes when compared with published maps of the same region. However, MAS was an efficient tool for selecting the desirable recombination events for these two pathogen resistance genes.
\end{abstract}

Although cultivar development for multiple pathogen resistance in tomato (Solanum lycopersicum L.) is a desirable goal, the

Received for publication 14 Apr. 2010. Accepted for publication 26 July 2010

${ }^{1}$ To whom reprint requests should be addressed; e-mail mikel_stevens@byu.edu. multiple pathogens (Yang and Francis, 2005) Marker-assisted selection (MAS) offers an opportunity to overcome some of the problems associated with phenotypic selection and facilitates combining multiple resistance genes.

Tomato spotted wilt virus (TSWV) and Phytophthora infestans (Mont.) de Bary (late blight) are responsible for substantial tomato crop losses worldwide (Foolad et al., 2008; Fry and Goodwin, 1997; Kim and Mutschler, 2005, 2006; Mumford et al., 1996; Roselló et al., 1996). Several resistance genes have been identified for both pathogens; however, two genes have been found to be especially valuable for their broad level of resistance to each of these pathogens (Foolad et al., 2008; Gordillo et al., 2008). Both genes, $S w-5$ for resistance to TSWV and $P h-3$ for resistance to $P$. infestans, were originally introgressed from wild relatives and confer high levels of pathogen resistance.

The TSWV resistance gene $S w-5$ was introgressed from $S$. peruvianum (previously Lycopersicon peruvianum Mill.; accession unknown) (Stevens, 1964; Stevens et al., 1992; van Zijl et al., 1986). This gene confers resistance to the Tospovirus species TSWV, Groundnut ringspot virus, and Tomato chlorotic spot virus (Bioteux et al., 1993; Stevens et al., 1992; van Zijl et al., 1986). The $P$. infestans resistance gene $P h-3$, derived from S. pimpinellifolium L. [formerly L. pimpinellifolium (Jusl). Mill. accession L3707], is of incomplete dominant inheritance; however, it confers strong resistance to a spectrum of $P$. infestans isolates, even when plants are heterozygous for this gene (AVRDC, 1998; Black et al., 1996a, 1996b; Chunwongse et al., 1998, 2002; Foolad et al., 2008; Gardner and Panthee, 2010).

$S w-5$ and $P h-3$ are tightly linked to the restriction fragment length polymorphism markers CT220 and TG591A, respectively (Brommonschenkel et al., 2000; Chunwongse et al., 1998, 2002; Folkertsma et al., 1999; Stevens et al., 1995). These two markers are near the telomere of the long arm of chromosome 9 and are separated by $5 \mathrm{cM}$ or less on the EXPEN 2000 and the EXPEN 1992 tomato maps (http://solgenomics.net; Tanksley et al., 1992). Because these two genes originate from different wild relatives of tomato, they are naturally linked in the repulsion phase. The phase and short genetic distance between them provide a potential challenge to recombining them into a coupling phase, a step needed for developing homozygous parent lines for hybrids and open-pollinated cultivars. An additional challenge is that a number of tomato breeding programs and studies have identified recombination suppression in chromosomal regions derived from wild relatives (Canady et al., 2005, 2006; Ganal and Tanksley, 1996; Liharska et al., 1996).

Because both TSWV and P. infestans can be devastating pathogens, the development of tomato germplasm homozygous for $S w-5$ and $P h-3$ enables the possibility of pyramiding $P h-1, P h-2$, and $P h-3$ with $S w-5$ and $S w-7$ for broader resistance than is presently available 
(Dockter et al., 2009; Foolad et al., 2008; Gordillo et al., 2008; Price et al., 2007; Scott et al., 2005). Therefore, the development of lines homozygous for both genes was the objective of this research. To overcome recombination suppression and avoid phenotypic screening of many individuals, we used MAS to quickly screen a large $F_{2}$ population for plants with potential crossovers placing $S w-5$ and $P h-3$ in the coupling phase. The selfed progeny of these recombinants were subsequently screened for resistance to each disease. Furthermore, we used the literature in combination with our data and the available tomato genome sequence to lay the foundation for cloning $P h-3$.

\section{Materials and Methods}

Plant material. An $\mathrm{F}_{2}$ population, segregating for $P h-3$ and $S w-5$, was derived from NC 946-1(2004)-11 $\times$ NC 0592-8-10 and was used to identify coupling phase $P h-3 / S w-5$ recombinants. NC 0592-8-10, designated as NC592, is a $P h-3 / P h-3$ inbred line and was derived from NC $0483 \times$ NC 25P (Gardner and Panthee, 2010), whereas NC 946-1(2004)11, designated as NC946, is a $\mathrm{Sw}-5 / \mathrm{Sw}-5$ inbred line derived from NC EBR-7 $\times$ 'Amelia'. A total of $1152 \mathrm{~F}_{2}$ plants were subjected to DNA marker analysis to identify recombinants between $P h-3$ and $S w-5$. Eleven recombinant $F_{2}$ plants were identified with the genes putatively in the coupling phase and were self-pollinated to create $F_{3}$ progeny. Because three were male sterile [ms-10 gene derived from the NC592 parent (Gardner, 2000; Gardner and Panthee, 2010)], eight $F_{2}$ recombinants produced seed in the greenhouse. For each of these eight recombinants, we transplanted 40 individual $\mathrm{F}_{3}$ plants for evaluation in the field in Wooster, $\mathrm{OH}$, in 2008. The $F_{3}$ plants were also genotyped by molecular markers to identify 65 individuals potentially homozygous for $S w-5$ and $P h-3$. These plants were visually inspected and 30 were retained and self-pollinated based on desirable characteristics of vine type, heavy fruit load, uniform fruit color, fruit shape, and fruit size. Among the 30 selected $\mathrm{F}_{3}$ plants were at least three representatives from each of the eight original $\mathrm{F}_{2}$ recombinants (Table 1). Additionally, $F_{5}$ progeny were created for confirmation of the original $\mathrm{F}_{2}$ recombinants 08-5401, 08-5403, and 08-5408.

Evaluation of disease resistance. TSWV maintenance and evaluation of resistant tomatoes was preformed as previously described (Canady et al., 2001; Gordillo et al., 2008; Stevens et al., 1992). Briefly, mechanical inoculation of the "HR-1" isolate was performed at least twice, 1 week apart, with controls [near isogenic tomato lines 89R ( $\mathrm{Sw}$ $5 / S w-5$; resistant $)$ and $89 \mathrm{~S}\left(S w-5^{+} / S w-5^{+}\right.$; susceptible)] included. HR-1 is an isolate derived from TSWV-infected field tomatoes in Hawaii. This isolate readily infects $S w-5^{+} /$ $S w-5^{+}$lines but does not infect $S w-5 / S w-5$ or $S w-5 / S w-5^{+}$genotypes. Plants with stunted growth, necrotic patches, or chlorotic ringspots were considered infected and scored as homozygous-susceptible $\left(S w-5^{+} / S w-5^{+}\right)$. Seven to 20 individual $F_{4}$ or $F_{5}$ progeny were rated for resistance to TSWV as R or S and the percentage of susceptible (S) progenies was calculated. Two separate evaluations were performed in 2008 and 2010 using progeny from different $\mathrm{F}_{3}$ recombinants (Table 1).

Phytophthora infestans resistance was evaluated using a detached leaf assay and field tests. Isolate $\mathrm{Ph} 2-\mathrm{OC}$, originating in tomato in North Carolina, overcomes $P h-2$, but not $P h-3$, and was maintained on live tomato plants. Lines NC 2CELBR ( $P h-3 / P h-3$; resistant) and NC 30P $\left(P h-3^{+} / P h-3^{+}\right.$; susceptible $)$were used as controls. Fully expanded young leaves with five leaflets were excised from each of six plants per line using a single-edge razor blade from greenhouse-grown plants. Each leaf was placed into $120 \mathrm{~mL}$ distilled water in a snap seal plastic sample container with a 1-cm hole in the center of the lid. Containers were placed in a clear plastic box and hand sprayed to atomize a sporangia suspension (5000 sporan$\mathrm{gia} / \mathrm{mL}$ of distilled water) of $\mathrm{Ph} 2-\mathrm{OC}$ until the upper surface of each excised tomato leaf was completely covered. The boxes were closed and placed in an incubator at $20 / 16^{\circ} \mathrm{C}$ for $12-\mathrm{h}$ photoperiods. Leaves of each line were evaluated after 1 week using a score from 1 to 5 (1 for no lesions and 5 for completely covered with lesions or dead). Fifteen resistant lines identified from the detached leaf tests were planted in the field in the summer in two locations (Mills River and Waynesville, NC) under natural inoculum without any fungicide spray. Individual plants were scored from 0 to 5 ( 0 for no lesions and 5 for completely covered with lesions or dead)

Molecular marker genotyping. Markerassisted selection for $P h-3$ and $S w-5$ was accomplished using previously identified markers. $P h-3$ was indirectly selected using the cleaved amplified polymorphic sequences (CAPS) markers TG328 and TG591 (M. Mutschler, personal communication). TG328 was detected using the primers $\left(5^{\prime}\right.$ to $\left.3^{\prime}\right)$ TG328F (GGTGATCTGCTTATAGACTTG GG) and TG328R (AAGGTCTAAAGAAG GCTGGTGC) and the restriction endonuclease $B s t$ NI. For TG591, the primers TG591F (AAGGCAAAGGAAGTTGGAGGTCA) and TG591R (AGAGGTTGCAACTCGTG GATTGAG) were used with AciI. Fragment sizes for TG328:Bst NI were $500 \mathrm{bp}$ (undigested) for the NC946 allele (T) and a 260/240-bp doublet for the NC592 allele (P). For the TG591:AciI digest, a multiple band phenotype was observed with the diagnostic polymorphism as a 150-bp fragment in NC946 (T) and a 160-bp fragment in NC592 (P).

To indirectly select for $S w-5$, the sequenced characterized amplified region (SCAR) marker SCAR421 was used (Anfoka et al., 2006; Folkertsma et al., 1999; Stevens et al., 1996). SCAR421 amplified a 940-bp fragment in NC946 (T allele associated with Sw-5) and a 920-bp fragment in NC592 (P allele). Each individual within all populations evaluated with markers was initially genotyped and then selections were sub- sequently resampled and genotyped for confirmation.

To determine marker genotypes, genomic DNA was isolated in 96-well format following the modified CTAB method described by Kabelka et al. (2002) and subjected to polymerase chain reaction (PCR). Conditions for PCR reactions were $10 \mathrm{~mm}$ Tris- $\mathrm{HCl}(\mathrm{pH}$ 8.3), $50 \mathrm{~mm} \mathrm{KCl}, 1.5 \mathrm{~mm} \mathrm{MgCl} 2,50 \mu \mathrm{M}$ of each dNTP, $0.1 \mu \mathrm{M}$ of each forward and reverse primers, $20 \mathrm{ng}$ of template DNA, and 1 unit of Taq DNA polymerase in a total volume of 10 to $20 \mu \mathrm{L}$. PCR amplification was performed using the cycling parameters of $30 \mathrm{~s}$ at $94{ }^{\circ} \mathrm{C}$ followed by 35 cycles of $20 \mathrm{~s}$ at $94{ }^{\circ} \mathrm{C}, 20 \mathrm{~s}$ at $55^{\circ} \mathrm{C}$, and $2 \mathrm{~min}$ at $72{ }^{\circ} \mathrm{C}$ followed by an extended incubation for $7 \mathrm{~min}$ at $72{ }^{\circ} \mathrm{C}$. For CAPS markers, PCR amplicons were digested with the appropriate restriction endonuclease by adding 0.08 to 0.16 units of enzyme in $1 \times$ digestion buffer for each microliter of PCR product. Markers were visualized as size polymorphisms by agarose gel electrophoresis. Genotype frequencies for all markers were tested for deviation from expected segregation ratios by a $\chi^{2}$ goodness-of-fit test. Map distances between markers were calculated from the genotypic data of the original $F_{2}$ population using JoinMap 3.0 (Van Ooijen and Voorrips, 2001). The markers were first grouped with a LOD of at least 10.0 and then the Kosambi mapping function was used to calculate the distance between markers in centiMorgans.

\section{Results and Discussion}

Selection of coupling phase recombinants using molecular markers. A total of $1152 \mathrm{~F}_{2}$ plants were genotyped with TG328, TG591, and SCAR421 to identify 24 recombinants with 11 potentially having both resistances in coupling phase. Of these 11, eight produced $\mathrm{F}_{3}$ progeny (Table 1 ). The observed recombination events suggested a marker order of TG328, TG591, and SCAR421, consistent with previous maps and the physical order of the markers on BAC clones for chromosome 9 (Folkertsma et al., 1999). However, recombination distances of $0.33 \mathrm{cM}$ between TG328 and TG591 and $0.78 \mathrm{cM}$ between TG591 and SCAR421 suggest that recombination was suppressed between the $S$. peruvianum introgression $(S w-5)$ and the $S$. pimpinellifolium introgression $(\mathrm{Ph}-3)$ segments. In contrast, markers TG328 and TG591 are separated by $1 \mathrm{cM}$ on the reference maps, whereas TG591 and SCAR421 (physically linked to CT220) are separated by $5.0 \mathrm{cM}$ (Pillen et al., 1996; Tanksley et al., 1992) on the EXPEN 2000 map (http://www. solgenomics.net). Suppression of recombination is not unexpected in introgressions (Canady et al., 2005, 2006; Ganal and Tanksley, 1996; Liharska et al., 1996; Zamir and Tadmor, 1986).

Confirmation of resistances of $F_{4}$ and $F_{5}$ progeny. For phenotypic confirmation, $\mathrm{F}_{3}$ and $\mathrm{F}_{5}$ progenies derived from each of the eight $F_{2}$ coupling phase recombinants were 
Table 1. Genotype $\left(\mathrm{F}_{2}\right.$ and $\left.\mathrm{F}_{3}\right)$ and phenotype $\left(\mathrm{F}_{4}\right.$ and $\left.\mathrm{F}_{5}\right)$ of individuals selected as coupling phase recombinants for Ph-3 (P. infestans) and $S w-5$ (TSWV) resistance genes in tomato.

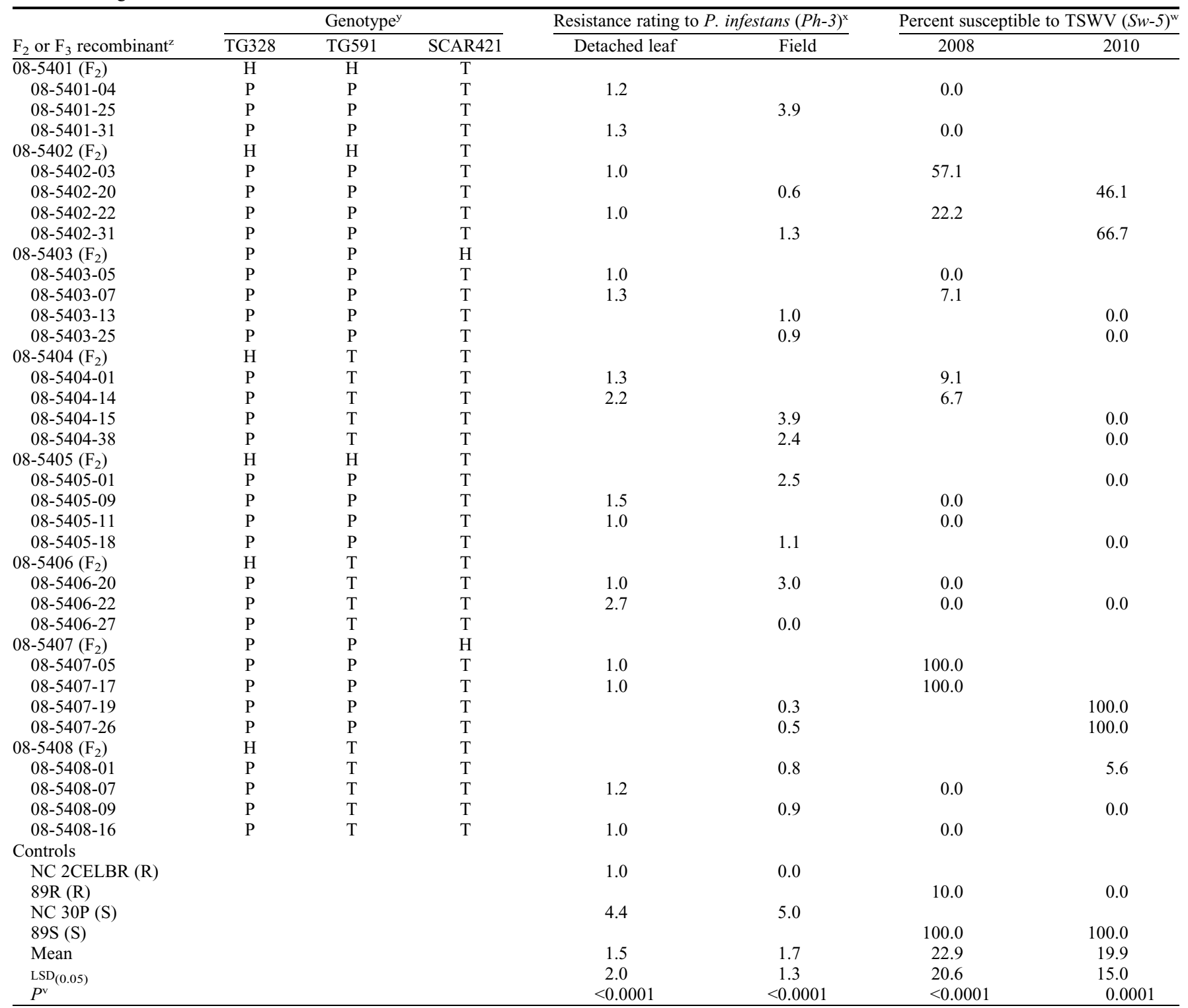

Note: $\mathrm{F}_{4}$ progeny from 08-5401-25 were not tested for TSWV because of lack of seed. $\mathrm{F}_{5}$ progeny from 08-5401-04, 08-5403-07, and 08-5408-07 were evaluated for TSWV in 2010 . All were $0.00 \%$ susceptible and matched the genotype of their respective $\mathrm{F}_{3}$ parent.

${ }^{7} \mathrm{~F}_{2}$ individuals were derived from a cross between resistant parents NC592 $(P h-3 / P h-3)$ and NC946 $(S w-5 / S w-5)$ and were selected for coupling phase recombination based on molecular markers. All other recombinants are $F_{3}$ individuals selected from the $F_{2}$ by markers for homozygous coupling phase recombination.

${ }^{\mathrm{y}}$ Genotype of the $\mathrm{F}_{2}$ or $\mathrm{F}_{3}$ individual. TG328 and TG591 are linked to $P h-3$ and SCAR421 is linked to $S w-5$. $\mathrm{H}=$ heterozygous; T = homozygous for the NC946 $(S w-5)$ allele; $\mathrm{P}=$ homozygous for the NC592 $(P h-3)$ allele.

${ }^{x}$ Mean ratings of individual $\mathrm{F}_{4}$ progeny scored for resistance to $P$. infestans based on 1-5 (detached leaf ratings) or $0-5$ (field ratings) scale ( 0 or 1 for no lesions and 5 for completely covered with lesions or dead).

${ }^{w}$ Individual $\mathrm{F}_{4}$ or $\mathrm{F}_{5}$ progeny were rated for resistance to TSWV as R or S and the percentage of susceptibility (S) progenies was calculated.

${ }^{v} P$ from analysis of variance for the test of the main effect of entries $\left(\mathrm{F}_{4}\right.$ or $\mathrm{F}_{5}$ progeny).

$\mathrm{TSWV}=$ Tomato spotted wilt virus; $\mathrm{R}=$ resistant; $\mathrm{S}=$ susceptible; $\mathrm{LSD}=$ least significant difference.

challenged with $P$. infestans and TSWV. Progeny derived from 08-5401, 08-5404, and 08-5406 were significantly more susceptible to $P$. infestans than the resistant control. These progeny were also more resistant than susceptible controls; thus, we considered the phenotype ambiguous. Progeny from at least five of the $\mathrm{F}_{2}$ recombinants were unambiguously resistant to $P$. infestans. The progeny derived from 08-5402 appeared to segregate or show less than complete resistance to TSWV, whereas families derived from 08-
5407 were fully susceptible. Families derived from 08-5403, 08-5405, and 085408 showed resistance to both pathogens (Table 1).

Genetic and physical order of the Ph-3 and Sw-5 genes. An insufficient number of recombinant plants were identified to accurately position $P h-3$ and $S w-5$ relative to the molecular markers. The small number of recombinants and the ambiguous scoring of progeny derived from $08-5401,08-5404$, and 08-5406 for P. infestans resistance and 08-
5402 for TSWV resistance further complicate our ability to accurately place the genes based on phenotyping only the coupling phase recombinants. Complete susceptibility to TSWV in progeny derived from 08-5407 strongly suggest linkage to SCAR421 was broken and that the $S w-5$ resistance gene cannot be distal to this marker and probably lies in the interval between TG591 and SCAR421. The most likely position of $P h-3$ is either the interval between TG328 and TG591 or distal to TG328. 
The marker and resistance gene order suggested by recombinant progeny is consistent with the physical organization of the $S w-5$ region of chromosome 9 . Sequence data for bacterial artificial chromosomes (BACs) are available from Folkertsma et al. (1999) and from the international tomato genome sequencing effort. Marker TG328 is not yet anchored to a BAC. Marker TG591 is anchored to a 110,571-bp BAC clone, C09Hba0165P17 (GenBank EF647605; GI: 149930469). BAC clones containing $S w-5$ family members $S w-5 a$ (AY007366) and $S w-5 c$ (AY007367) have been sequenced (Folkertsma et al., 1999). These include a 35,250-bp BAC containing the $S w-5$ locus (GenBank AY007366; GI: 15418708) with significant homology to the 114,526-bp BAC, C09HBa109D11 (GenBank EF647603; GI: 149930467), and the 113,581bp BAC clone C09Hba226D21 (GenBank EU139072; GI: 157649058). The $3^{\prime}$ end of C09Hba109D11 overlaps with the $5^{\prime}$ end of clone $\mathrm{C} 09 \mathrm{Hba} 226 \mathrm{D} 21$ suggesting a possible contiguous sequence. CT202 is anchored to a 95,676-bp BAC Hba0059I05 (SGN only, because this sequence was not yet deposited in GenBank at the time of this writing). The marker SCAR421 is physically linked to CT202 within $\approx 65 \mathrm{~Kb}$ (Folkertsma et al., 1999). The $5^{\prime}$ region of BAC Hba0059I05 has homology to C09Hba109D11 and homology to the $S w-5 a$ protein. The $3^{\prime}$ end of BAC Hba0059I05 95676 has no significant homology to sequences in the NCBI database. The fact that this region contains homology to a number of resistance gene families, including $S w-5$ family members (C09Hba109D11, C09Hba226D21, and Hba0059I05), the Tm-2 ${ }^{a}$ gene (C09Hba0165P17), and homologs to Phytophthora resistance genes $(\mathrm{C} 09 \mathrm{Hba} 0165 \mathrm{P} 17)$ from the wild potato $S$. venturii (Foster et al., 2009; Lanfermeijer et al., 2003; Pel et al., 2009), suggests that caution should be used in defining contiguous sequences until more complete data are available. Based on available genetic and physical data, it appears that the members of the $S w-5$ family responsible for TSWV resistance lie within the interval defined by TG591 and CT202 with SCAR421 distal (Brommonschenkel et al., 2000; Folkertsma et al., 1999; this article). Our data suggest that the likely position for $P h-3$ is between TG328 and TG591. The occurrence of several resistance gene homologs on BAC clones containing TG591 suggests possible candidates. Based on the length of the sequenced BAC clones, it appears that the position of $P h-3$ is likely to be physically separated from $S w-5$ by over 100,000 bp despite the low genetic distance separating the loci in the NC592 × NC946 cross.

\section{Literature Cited}

Anfoka, G.H., M. Abhary, and M.R. Stevens. 2006. Occurrence of Tomato spotted wilt virus (TSWV) in Jordan. EPPO Bulletin 36:517522.

AVRDC. 1998. AVRDC Report 1997. Asian Vegetable Research and Development Center, Shanhua, Tainan, Taiwan.
Bioteux, L.S., T. Nagata, and L.B. Giordano. 1993. Field resistance of tomato Lycopersicon esculentum lines to tomato spotted wilt disease. Rep. Tomato Genet. Coop. 43:7-9.

Black, L.L., T.C. Wang, P.M. Hanson, and J.T Chen. 1996a. Late blight resistance in four wild tomato accessions, effectiveness in diverse locations and inheritance of resistance. Phytopathology 86:S24.

Black, L.L., T.C. Wang, and Y.H. Huang. and AVRDC. 1996b. New sources of late blight resistance identified in wild tomatoes. Tropical Vegetable Information Service Newsletter 1: 15-17.

Brommonschenkel, S.H., A. Frary, and S.D. Tanksley. 2000. The broad-spectrum tospovirus resistance gene $S w-5$ of tomato is a homo$\log$ of the root-knot nematode resistance gene Mi. Mol. Plant Microbe Interact. 13:11301138.

Canady, M.A., Y.F. Ji, and R.T. Chetelat. 2006. Homeologous recombination in Solanum lycopersicoides introgression lines of cultivated tomato. Genetics 174:1775-1788.

Canady, M.A., V. Meglic, and R.T. Chetelat. 2005. A library of Solanum lycopersicoides introgression lines in cultivated tomato. Genome 48 685-697.

Canady, M.A., M.R. Stevens, M.S. Barineau, and J.W. Scott. 2001. Tomato spotted wilt virus (TSWV) resistance in tomato derived from Lycopersicon chilense Dun. LA 1938. Euphytica 117:19-25.

Chunwongse, J., C. Chunwongse, L. Black, and P. Hanson. 2002. Molecular mapping of the $P h-3$ gene for late blight resistance in tomato. $\mathrm{J}$. Hort. Sci. Biotechnol. 77:281-286.

Chunwongse, J., C. Chunwongse, L.L. Black, and P.M. Hanson. 1998. Mapping of the $P h$ 3 gene for late blight from L. pimpinellifolium L3708. Rep. Tomato Genet. Coop. 48: 963-971.

Dockter, K.G., D.S. O’Neil, D.L. Price, J. Scott, and M.R. Stevens. 2009. Molecular mapping of the Tomato spotted wilt virus resistance gene $S w-7$ in tomato. HortScience 44 1123 .

Folkertsma, R.T., M.I. Spassova, M. Prins, M.R. Stevens, J. Hille, and R.W. Goldbach. 1999. Construction of a bacterial artificial chromosome (BAC) library of Lycopersicon esculentum cv. Stevens and its application to physically map the $S w-5$ locus. Mol. Breed. 5: 197-207.

Foolad, M.R., H.L. Merk, and H. Ashrafi. 2008. Genetics, genomics and breeding of late blight and early blight resistance in tomato. Crit. Rev. Plant Sci. 27:75-107.

Foster, S.J., T.H. Park, M. Pel, G. Brigneti, J. Sliwka, L. Jagger, E. van der Vossen, and J.D.G. Jones. 2009. Rpi-vnt1.1, a Tm- $2^{2}$ homo$\log$ from Solanum venturii, confers resistance to potato late blight. Mol. Plant Microbe Interact. 22:589-600.

Fry, W.E. and S.B. Goodwin. 1997. Re-emergence of potato and tomato late blight in the United States. Plant Dis. 81:1349-1357.

Ganal, M.W. and S.D. Tanksley. 1996. Recombination around the $T m 2 a$ and $M i$ resistance genes in different crosses of Lycopersicon peruvianum. Theor. Appl. Genet. 92:101-108.

Gardner, R.G. 2000. A male-sterile cherry tomato breeding line, $\mathrm{NC} 2 \mathrm{C} m s-10, a a$. HortScience 35:964-965.

Gardner, R.G. and D.R. Panthee. 2010. 'Plum Regal' fresh-market plum tomato hybrid and its parents, NC 25P and NC 30P. HortScience 45:824-825.
Gordillo, L.F., M.R. Stevens, M.A. Millard, and B. Geary. 2008. Screening two Lycopersicon peruvianum collections for resistance to Tomato spotted wilt virus. Plant Dis. 92:694704.

Kabelka, E., B. Franchino, and D.M. Francis. 2002. Two loci from Lycopersicon hirsutum LA407 confer resistance to strains of Clavibacter michiganensis subsp. michiganensis. Phytopathology 92:504-510.

Kim, M.J. and M.A. Mutschler. 2005. Transfer to processing tomato and characterization of late blight resistance derived from Solanum pimpinellifolium L. L3708. J. Amer. Soc. Hort. Sci. 130:877-884.

Kim, M.J. and M.A. Mutschler. 2006. Characterization of late blight resistance derived from Solanum pimpinellifolium L3708 against multiple isolates of the pathogen Phytophthora infestans. J. Amer. Soc. Hort. Sci. 131:637645.

Lanfermeijer, F.C., J. Dijkhuis, M.J.G. Sturre, P. de Haan, and J. Hille. 2003. Cloning and characterization of the durable Tomato mosaic virus resistance gene $T m-2^{2}$ from Lycopersicon esculentum. Plant Mol. Biol. 52:10371049.

Liharska, T., M. Koornneef, M. vanWordragen, A. vanKammen, and P. Zabel. 1996. Tomato chromosome 6: Effect of alien chromosomal segments on recombinant frequencies. Genome 39:485-491.

Mumford, R.A., I. Barker, and K.R. Wood. 1996. The biology of the Tospoviruses. Ann. Appl. Biol. 128:159-183.

Pel, M.A., S.J. Foster, T.H. Park, H. Rietman, G. van Arkel, J.D.G. Jones, H.J. van Eck, E. Jacobsen, R.G.F. Visser, and E.A.G. van der Vossen. 2009. Mapping and cloning of late blight resistance genes from Solanum venturii using an interspecific candidate gene approach. Mol. Plant Microbe Interact. 22:601615.

Pillen, K., O. Pineda, C.B. Lewis, and S.D. Tanksley. 1996. Status of genome mapping tools in the taxon Solonaceae, p. 281-308. In: Paterson, A.H. (ed.). Genome mapping in plants. Academic Press, Austin, TX.

Price, D.L., J.W. Memmott, J.W. Scott, S. Olson, and M.R. Stevens. 2007. Identification of molecular markers linked to a new Tomato spotted wilt virus resistance source in tomato. Rep. Tomato Genet. Coop. 57:35.

Roselló, S., M.J. Díez, and F. Nuez. 1996. Viral diseases causing the greatest economic losses to the tomato crop. I. The Tomato spotted wilt virus-A review. Sci. Hort. 67:117150.

Scott, J.W., M.R. Stevens, and S.M. Olson. 2005. An alternative source of resistance to Tomato spotted wilt virus. Rep. Tomato Genet. Coop. 55:40-41.

Stevens, J.M. 1964. Tomato breeding. Dept. Agricultural Technical Services, Republic of South Africa, Project Report W-Vv1.

Stevens, M.R., D.K. Heiny, P.D. Griffiths, J.W. Scott, and D.D. Rhoads. 1996. Identification of co-dominant RAPD markers tightly linked to the Tomato spotted wilt virus (TSWV) resistance gene $S w-5$. Rep. Tomato Genet. Coop. 46: $27-28$.

Stevens, M.R., E.M. Lamb, and D.D. Rhoads. 1995. Mapping the $S w-5$ locus for Tomato spotted wilt virus resistance in tomatoes using RAPD and RFLP analyses. Theor. Appl. Genet. 90:451-456.

Stevens, M.R., S.J. Scott, and R.C. Gergerich. 1992. Inheritance of a gene for resistance to 
Tomato spotted wilt virus (TSWV) from Lycopersicon peruvianum Mill. Euphytica 59: 9-17.

Tanksley, S.D., M.W. Ganal, J.P. Prince, M.C. de Vicente, M.W. Bonierbale, P. Broun, T.M. Fulton, J.J. Giovannoni, S. Grandillo, G.B. Martin, R. Messeguer, J.C. Miller, L. Miller, A.H. Paterson, O. Pineda, M.S. Roder, R.A. Wing, W. Wu, and N.D. Young. 1992. High density molecular linkage maps of the tomato and potato genomes. Genetics 132:1141 1160.

Van Ooijen, J.W. and R.E. Voorrips. 2001. JoinMap ${ }^{\circledR}$ 3.0, software for the calculation of genetic linkage maps. Plant Research International, Wageningen, The Netherlands.

van Zijl, J.J.B., S.E. Bosch, and C.P.J. Coetzee. 1986. Breeding tomatoes for process- ing in South Africa. Acta Hort. 194:6975 .

Yang, W.C. and D.M. Francis. 2005. Markerassisted selection for combining resistance to bacterial spot and bacterial speck in tomato. J. Amer. Soc. Hort. Sci. 130:716-721.

Zamir, D. and Y. Tadmor. 1986. Unequal segregation of nuclear genes in plants. Bot. Gaz. 147: 355-358. 